The International J ournal of the First Year in Higher Education ISSN: 1838-2959

Volume 4, Issue 2, pp. 27-37

August 2013

\title{
Transforming learning through capacity-building: Maximising life and learning support to mobilise diversities in an Australian pre-undergraduate preparatory program
}

\author{
Phyllida Coombes^, Patrick Danaher* and Geoff Danaher^ \\ *University of Southern Queensland, Toowoomba, Australia \\ ${ }^{\wedge}$ Independent Scholars
}

\begin{abstract}
One key manifestation of educational diversity is low socioeconomic status students and those who are otherwise marginalised from accessing higher education. This exploratory case study outlines and evaluates a long-running Australian pre-undergraduate preparatory program directed at providing maximum life and learning support to students by means that engage with and build on their diversities. Data are drawn from semi-structured focus groups with successive cohorts of students and theoretically-informed reflections by program staff members. The analysis of these data is framed by the conceptual blending of current theorising about transformative learning and capacity-building, which in combination constitute a powerful lens for illuminating student diversity in higher education. Based on that analysis, despite some inevitable limitations, the program is largely successful in its strategies to maximise life and learning support in order to mobilise the students' diversities in ways that enhance their current and prospective learning outcomes.
\end{abstract}

Please cite this article as:

Coombes, P., Danaher, P., \& Danaher, G. (2013). Transforming learning through capacity-building: Maximising life and learning support to mobilise diversities in an Australian pre-undergraduate preparatory program. The International Journal of the First Year in Higher Education, 4(2). 27-37. doi: 10.5204/intjfyhe.v4i2.169

This article has been peer reviewed and accepted for publication in Int J FYHE. Please see the Editorial Policies under the 'About' section of the Journal website for further information.

(C) Copyright of articles is retained by author/s. As an open access journal, articles are free to use, with proper attribution, in educational and other non-commercial settings. ISSN: 1838-2959 


\section{Introduction}

Ten years ago, the authors of this text contributed a paper (Simpson et al., 2003) to the $7^{\text {th }}$ Pacific Rim First Year in Higher Education Conference that contested homogeneous understandings of "the first year experience" in favour of more differentiated and heterogeneous approaches to conceptualising that experience. One of the three programs used in that paper to underscore this argument (see also Willans, Harreveld, \& Danaher, 2003) is again interrogated in this paper, this time with different empirical data and an alternative conceptual framework. Then the focus was on the notion of the habitus (Bourdieu, 1977, 1990); now the theoretical lens is a blend of transformative learning and capacity-building.

More specifically, this paper analyses and evaluates the pre-undergraduate preparatory program at an Australian university in terms of its specific strategies aimed at providing maximum life and learning support for its highly diverse and heterogeneous student groups. Despite some inevitable limitations, the program is demonstrated as being successful for more than 25 years in enhancing the students' learning outcomes during and after the program and in assisting them sustainably to realise their potential in higher education.

The paper consists of the following four sections:

- A selected literature review and conceptual framework and the study's research design

- The presentation of data

- The analysis of those data

- Concluding implications of the data analysis for students from diverse backgrounds realising their potential in higher education.

\section{Literature review, conceptual framework and research design}

Notions of student diversity are themselves diverse and reflective of a wide variety of ideological and political positions about what such diversity is and why it is important (Bowser, Danaher, \& Somasundaram, 2007). Life and learning support for higher education students is similarly diverse, ideological and politicised (see also Lee, Srinivasan, Trail, Lewis, \& Lopez, 2011). This is because of the variety of beliefs about who should gain access to university study: those favouring a meritocratic approach would be likely to endorse a more restricted range of support structures than those who see such support as indispensable in helping students who would not otherwise attend university to bridge the two fieldseven the two worlds-of home and study. The complexity of the situation was encapsulated by Clegg's (2011) caution against "a deficit view of students from less privileged backgrounds", her insistence on the importance of "... conceptualising the resilience of those from less privileged backgrounds" and her view that "... a curriculum that acknowledges the context independence of knowledge is essential if these students are not to be further disadvantaged" (p. 93).

As we noted above, the conceptual lens deployed to examine the program in terms of its life and learning support strategies and its mobilisation of students' diversities is a blend of transformative learning and capacity-building. The literature on each of these fields is vast. Despite recent contestations of the utility of transformative learning (Newman, 2012), 
evidence abounds that appropriately designed programs and courses can generate sustained transformations of learning and students' associated perspectives and worldviews (Gutiérrez \& Vossoughi, 2010; Sugrue, 2011), including for higher education students who are variously identified as disadvantaged or marginalised (Bridwell, 2013; Chen, 2012; Mackinlay \& Barney, 2010).

We see capacity-building (Danaher et al., 2012) as intersecting with, and as helping to focus and augment, transformative learning (Dryzek, 2009). This view recognises the specific literacies, skills and other specialised knowledges that underpin capacity-building (Patrick \& Ijah, 2012) and that are crucial to grounding transformative learning and giving it momentum.

The pre-undergraduate preparatory program under review here, called Skills for Tertiary Education Preparatory Studies (STEPS), began in 1986 at Central Queensland University, and has been the subject of a growing body of scholarship (see for example Danaher, McDougall, Sturgess, \& Todorovic, 2008; Doyle, 2006; Willans, 2010). The program contains both face-to-face and online elements, and provides specialised support in computer skills, literacy and numeracy. Its clientele, who must be aged at least 19, are highly diverse in terms of age, background, ethnicity, gender and socioeconomic status, yet they have in common a generally negative schooling experience and a disconnect from the discourses of formal education. On that basis, we have previously argued (Simpson et al., 2003; Willans et al., 2003) in favour of considering the program as constituting a distinctive and vital dimension of "the first year experience" of university education.
The data presented here derive from a large-scale, qualitative, exploratory case study (Silverman, 2011; Swanborn, 2010) centred on the program and its transformative potential. The principal data gathering technique has been semistructured focus groups with students with appropriate ethical clearance and informed consent, augmented by the academics' and managers' reflections gleaned from the aforementioned scholarly publications. Data have been interpreted by means of content analysis (Krippendorff, 2012), thematic analysis (Buetow, 2010) and discourse analysis (Van Dijk, 2011) in accordance with the respective investigators' research questions.

\section{Presentation of data}

In the previous section of this paper, the diversity of the students participating in a particular pre-undergraduate preparatory program has been acknowledged and supported by continuing research. Comparison and contrast between traditional and non-traditional university students are particularly relevant in this context-in particular, their attitudes towards learning. For traditional students, formal education has been an important focus in their lives for at least the past 12 years as they progress from primary to secondary schooling, and the fact that they have achieved the right to enrol in tertiary studies is a clear indication of success, based on hard work, especially in the final years at school.

For the non-traditional students considered in this paper, their experiences of formal education have been very different. For many, their last school attendance occurred some years ago and, as they readily acknowledge, many regard themselves as failed learners. Most left school as soon as legally possible for a 
variety of reasons and tended to find their work choices limited to low-skilled and low-paid jobs or even unemployment. One of the first questions that researchers need to ask is why, after such damaging educational experiences, these people should choose to embark on a preparatory program as a precursor towards an undergraduate degree.

As we noted above, research with the students enrolled in this preundergraduate preparatory program has been ongoing, dating back to its inception in 1986. To a considerable degree, the researchers have included teaching and management staff involved in the program, while interest in the findings has, over a period of time, extended to former students and tutors as well as others within the field of educational research. A wide range of qualitative and quantitative research techniques has proved effective, in particular those found to be suitable for producing the synthesised data analysed in this paper. These include semi-structured focus groups, with an emphasis on ethnography and theoretically formed reflections by staff members. It is the aim of this section of the paper to demonstrate how such data can relate to the provision of life and learning support for the students.

The students tend to react positively to the interview techniques used in the program. From initial diffidence, they soon become willing to share their thoughts and feelings with regard to the learning journeys that they have chosen to undertake. All students participate in interviews during the enrolment process where questions focus mainly on their reasons for wishing to embark on undergraduate studies and what they hope to gain from the experience. Most indicate some feelings of uncertainty and trepidation, scarcely surprising in view of often very negative attitudes towards their past schooling and their total unfamiliarity with the university. During the relatively short period of the program (six months fulltime), these students are offered ample opportunities to continue to express their hopes and fears with regard to their studies, either through the normal practices of the course material or through voluntary participation in focus group interviews. Narrative has proved to be an effective technique. As students and tutors share their stories, because focus group interviews tend to be a two-way process they become more familiar with one another. For example, students are encouraged to learn about and recognise their own preferred learning styles (Komarraju, Karau, Schmeck, \& Avdic, 2011), and to develop strategies for their use during the course of the program. Research tends to indicate that, while the students might need to learn the skills necessary for undergraduate studies, particularly in the fields of written and oral communication, basic mathematics and computing, their life experiences have contributed to certain capacities of which they may be unaware (Simpson et al., 2003; Willans et al., 2003; see also Carson, 2009).

While it is difficult to deny that competition is a significant element in contemporary universities, the ethos of the preparatory program under review here is based on collaboration. Despite the wide diversity among students in terms of prior experiences, culture, age, capabilities and worldviews, they share similar attitudes towards their future changes of success at undergraduate level, feelings that often undergo remarkable transformation as the course progresses and greater self-esteem becomes evident. Because the program is not based on competition, collaboration is 
explicitly and actively encouraged. Students share their ideas, discoveries and feelings with one another, with their teachers and with their families through study groups, class discussions, conversations during breaks from study or the more formal mechanism of data collection. Collaborative research between members of staff seemed almost inevitable, arising from a common concern with their students. As a result, they have shared the collection of data from focus group interviews and the writing and presentation of journal articles, book chapters and conference papers (for a similar approach in a different research team in another university, see also Arden et al., 2010). Such collaboration allows staff and students to learn about themselves and one another, and to analyse the strategies necessary for effective life and learning support. Through this process, students develop the ability to identify, understand and value their own capacities and capabilities.

The following is a necessarily limited selection of representative statements by students reflecting on their situations prior to the program as well as on the program's impact on their learning and their lives (see also Danaher, Cook, Danaher, Coombes, \& Danaher, in press). For ease of cross-reference with the next section of the paper, students have been assigned pseudonyms

Matthew: Whilst at school my Aboriginality was continually challenged by teachers and some students, which got my back up and led to many physical altercations .... I thought, "Why should I go to school if the principal and teachers are going to cane me?", so I only started to attend school for sporting events. When I left school I could not read or write. (As cited in Doyle, 2006, p. 121)
Nina: I had a disrupted childhood and had attended 11 primary schools before my troubled high school years. By my second year of high school, I was constantly in trouble, a truant and the brunt of several high school bullies' taunts. (As cited in Doyle, 2006, p. 132)

Both these students experienced significant academic and career achievement as a result of participating in the program, becoming respectively a Doctor of Philosophy candidate and a general practitioner registrar in a paediatric department. Eventual success came also to another student, Cecilia, who recalled growing up in New Zealand amidst a background of "significant sexual, physical and emotional abuse where education was given no value" (as cited in Doyle, 2006, p. 135). After the program, she completed a Bachelor of Arts degree, taught English in the Republic of Korea and has worked in child safely in Canberra and Queensland. She reflected: "Through STEPS, I gained the ability to learn and think in different ways, as well as a new understanding of myself and the world we live in" (as cited in Doyle, p. 136).

Another student was Tom, who had been a grazier for much of his 56 years:

I came from a background of - I guess you would call it narrow-mindedness .... Coming to STEPS with a totally different group of people you appreciate so much because they were so open and worldly and it gives me a new perspective on the community, on life and when I do the degree I've an ambition to help other producers to see other angles of the world. There's more things out there than growing grain .... I know there's a need for people to communicate ... to help families on farms. (As cited in McConachie \& Simpson, 2003, p. 116) 
A different student, Sam, recorded the program's inter-generational dimension:

My parents have been excited about the ... program themselves and the results I was able to achieve .... They have decided they would like to look at doing the ... program in the future now that they have seen that I have been able to do something with my life. It is interesting how it affects the older generation but they can learn and have said to themselves, "If my son can do it then so can we". (As cited in McConachie \& Simpson, 2003, p. 101)

Finally, William was another student who also commented on this perceived broader impact of the program:

If I looked at my life seven years ago I never dreamed I'd be able to go to university. From my background, it seemed only rich people went to university - the people that had a decent sort of education - whereas my family had no striving whatsoever to better themselves in that vein at all. So generations to come are going to be changed because of my involvement with the ... program. (As cited in McConachie \& Simpson, 2003, p. 117)

\section{Analysis of data}

As we noted earlier, the analysis of these data has been facilitated by blending current theorising about transformative learning and capacity-building. The theory of transformative learning, developed by theorists such as Mezirow (2012) and Cranton (Cranton, 2010; Kucukaydin \& Cranton, 2012a, 2012b) (see also Taylor, Cranton, \& Associates, 2012), has been well-documented. At its core is the notion that, when an individual is faced with a disorienting dilemma and through critical self-reflection is made aware that his/her own particular attitude might be limited or distorted in some way, this makes possible an alternative viewpoint and thus perhaps some form of transformation. The students who have played their part in this research study have to some extent participated in this transformative experience. Facing the dilemma of limited career options, individuals might choose to question their existing assumptions and beliefs, engaging in discourse with others in a similar situation and reflecting more deeply and critically on possible ways to remedy the situation. The decision to undertake preparatory and undergraduate studies will prove to be both daunting and potentially transformative, and will be likely to lead to an ongoing process of further reflection and transformation as more disorienting dilemmas are encountered. Thus, for example, as students acquire the capacity for effective critical reflection, their belief in their own abilities changes; failed learners can transform into effective and capable learners.

Like transformative learning, capacitybuilding derives from multiple disciplines and scholarly streams of thought. One such stream is Sen's (1999) capability approach, which positions capacity-building in the context of development studies as a kind of freedom (see also Arden et al., 2010; Harreveld, 2010; Harreveld \& Singh, 2008). This possibility becomes apparent as students learn to recognise and understand their own capacities for progressing from their former lifestyle and all that it entailed to undertaking and completing undergraduate studies. As the research data have revealed, a particular element of this empowerment relates to an increasing freedom of choice and opportunity. Capacity-building may therefore be described as including the following elements for current and subsequent students: individual and collaborative 
learning; maximised cultural and economic capital; and the development of selfesteem.

As we stated at the outset of this paper, we have found from the research data that transformative learning and capacitybuilding combine effectively as a legitimate theoretical basis for conducting research with non-traditional students as well as a powerful lens for illuminating and interpreting student diversity in higher education. This is so partly because transformative learning and capacitybuilding are both crucial elements of the learning process, and through continuous research teachers develop strategies to provide optimum life and learning support, while learners discover the best means available to ensure success in their endeavours.

These important points were illustrated clearly in the data outlined in the previous section. All six students whose voices were portrayed reported significant change in their lives that from varied perspectives constituted different kinds of transformative learning. Matthew experienced the transformation from truanting from school to undertaking doctoral studies at university. Nina also moved from being a school truant to a general practitioner registrar. Cecilia built on the trauma of abuse to work in child safety. Tom articulated a considerable change in his outlook and worldview, thereby gaining a wider appreciation of learning and life beyond the confines of his grain farm. Sam expressed delight that his parents were considering applying to enter the program, having seen the success that it had wrought in him. And William identified a veritable generational shift away from the lack of educational aspiration evidenced by his parents to presumed ongoing engagement in higher education for his children and their children.

Despite their considerable diversity, all these changes constituted significant and ongoing transformations in the lives of the students and their families. They also encapsulated transformative learning, with the associated acquisition of powerful new knowledge and skills and the radical alterations in existing understandings in favour of more enabling and productive worldviews. Certainly all the students' reported experiences, and their interpretations of those experiences, accorded with the multifaceted depiction of transformative learning "as cognitive and rational, as imaginative and intuitive, as spiritual, as related to individuation, as relational, and as relating to social change" (Cranton \& Taylor, 2012, p. 7). Similarly, all six transformative learners depicted in the previous section exhibited what are simultaneously a non-negotiable condition and a key corollary of such learning: the roles and responsibilities of adult learners working to facilitate that learning:
The broader purpose, the goal, of adult education is to help adults realize their potential for becoming more liberated, socially responsible, and autonomous learners - that is, to make more informed choices by becoming more critically reflective ... in their engagement in a given social context. Adult educators actively strive to extend and equalize the opportunities for them to do so. (Mezirow, 2012, p. 92)

These asserted roles and responsibilities of adult educators (Mezirow, 2012) are helpful in linking transformative learning and capacity-building, by highlighting the need for learners to acquire contextually specific skills as well as wider understandings if their learning is to be 
potentially transformative. With the six learners whose voices were heard in the previous section, their associated discourses and those of many of their fellow students identified specialised capacities that they had developed and practised through repetition in order to be able to apply in appropriate situations. These capacities ranged broadly, from knowing the conventions of essay writing to mastering the anxiety associated with speaking in public to becoming skilled at various computer programs to responding positively to constructive feedback to managing time commitments and multiple competing demands to growing the habitus (Bourdieu, 1977, 1990) of a university student (Simpson et al., 2003). This approach aligns with the acknowledgment of the need to develop specialised capacities for students from nontraditional backgrounds (Daddow, Moraitis, \& Carr, 2013; Janks, 2012).

\section{Conclusion}

Ten years ago (Simpson et al., 2003; Willans et al., 2003), we contended that the Australian pre-undergraduate preparatory program under review in this paper demonstrated part of the rich diversity and heterogeneity composing "the first year experience" in higher education. Since its inception, data have been collected in an ongoing case study. Drawing on these data, we have asserted that, while allowing for some inevitable limitations, the program has been consistently successful in maximising the students' learning outcomes during and after the program, and in assisting them to realise their potential in higher education.

A key element of that success has undoubtedly been the provision of carefully targeted life and learning support in the program. Some indicators of the character of such support were encapsulated in the six students' quoted statements about the program, including a welcoming and encouraging classroom climate, invitations to reflect on the progress of learning, tailoring assessment tasks to build on students' prior experiences and additional opportunities to reinforce required information in the respective courses in the program. This intentional alignment between the life and learning dimensions of the program and its support provision has been essential to assisting students to demonstrate the attainment of appropriate learning outcomes.

More broadly, we argue that there is a complex, critical and compelling set of connections among the three principal aspects of this paper: life and learning support; transformative learning and capacity-building; and the mobilisation of students' diversities in contemporary higher education. Those diversities mandate a more comprehensive and nuanced understanding of and approach to providing life and learning support, which must extend beyond formal academic tutoring to include the non-academic but in many cases even more significant dimensions of students' contexts and hence their likelihood of remaining at university. Transformative learning and capacitybuilding, considered separately and severally, provide indispensable insights into possible teaching methods as well as constituting particular kinds of learning outcomes and graduate attributes that can and should result if the other elements are successfully in place. And those outcomes and attributes in turn feed into affirming, strengthening and valuing the diversities of students that are central to the long-term survival and success of contemporary universities. 


\section{Acknowledgments}

The authors are grateful to the students, academics and managers participating in the program discussed in this paper, the final version of which has been enhanced by the constructive feedback of two anonymous peer reviewers. Adjunct Professor John Clarke has been an encouraging and facilitative editor.

\section{References}

Arden, C., Danaher, P., De George-Walker, L., Henderson, R., Midgley, W., Noble, K., \& Tyler, M. (Eds.), (2010). Sustaining synergies: Collaborative research and researching collaboration. Mount Gravatt, Australia: Post Pressed.

Bourdieu, P. (1977). Outline of a theory of practice (R. Nice, Trans.). Cambridge, UK: Cambridge University Press.

Bourdieu, P. (1990). The logic of practice (R. Nice, Trans.). Cambridge, UK: Polity Press.

Bowser, D., Danaher, P., \& Somasundaram, J. (2007, October-December). Teaching in Higher Education, 12(5-6), 669-681. doi: $10.1080 / 13562510701596224$

Bridwell, S. (2013, May). A constructivedevelopmental perspective on the transformative learning of adults marginalized by race, class, and gender. Adult Education Quarterly: A Journal of Research and Theory, 63(2), 127-146. doi: $10.1177 / 0741713612447854$

Buetow, S. (2010). Thematic analysis and its reconceptualization as 'saliency analysis'. Journal of Health Services Research \& Policy, 15(2), 123-125. doi: 10.1258/jhsrp.2009.009081

Carson, T. (2009, April). A history of equity in higher education in Australia: Making universities more accessible for students from disadvantaged backgrounds. Widening Participation and Lifelong Learning, 11(1), 5-16. Retrieved from http://wplljournal.metapress.com/content/24k3535t $1513 \mathrm{~g} 07 \mathrm{q} / \mathrm{p}=9523223891 \mathrm{db} 4 \mathrm{bc} 4926223$ 61aa0559a8\&pi=1
Chen, P. (2012, May). Empowering identity reconstruction of Indigenous college students through transformative learning. Educational Review, 64(2), 161-180. Retrieved from http://www.tandfonline.com/doi/full/10.1 $\underline{080 / 00131911.2011 .592574}$

Clegg, S. (2011, January). Cultural capital and agency: Connecting critique and curriculum in higher education. British Journal of Sociology of Education, 32(1), 93-108. doi: $10.1080 / 01425692.2011 .527723$

Cranton, P. (2010). Transformative learning in an online environment. International Journal of Adult Vocational Education and Technology, 1(2), 1-9. doi: 10.4018/javet.2010040101

Cranton, P., \& Taylor, E. (2012). Transformative learning theory: Seeking a more unified theory. In E. Taylor, P. Cranton, \& Associates (Eds.), The handbook of transformative learning: Theory, research, and practice (pp. 3-20). San Francisco, CA: Jossey-Bass.

Daddow, A., Moraitis, P., \& Carr, A. (2013, May). Nontraditional students in tertiary education: Inter-disciplinary collaboration in curriculum and pedagogy in community services education in Australia. International Journal of Inclusive Education, 17(5), 480-489. doi: 10.1080/13603116.2012.685765

Danaher, G., McDougall, J., Sturgess, P., \& Todorovic, V. (2008). Changing university learning and teaching from the outside in: The role of discussion forums in supporting student leadership in the STEPS external preparatory program. In J. McConachie, M. Singh, P. A. Danaher, F. Nouwens, \& G. Danaher (Eds.), Changing university learning and teaching: Engaging and mobilising leadership, quality and technology (pp. 305-320). Teneriffe, Australia: Post Pressed.

Danaher, M., Cook, J., Danaher, G., Coombes, P, \& Danaher, P. (in press). Researching education with marginalised communities. London, UK: Palgrave Macmillan.

Danaher, P., De George-Walker, L., Henderson, R., Matthews, K., Midgley, W., Noble, K., Tyler, M., \& Arden, C. (Eds.) (2012). Constructing capacities: Building capabilities through learning and engagement. Newcastle upon Tyne, UK: Cambridge Scholars Publishing. 
Doyle, S. (2006). STEPS: Celebrating 20 years: 19862006. Rockhampton, Australia: Central Queensland University.

Dryzek, J. (2009, November). Democratization as deliberative capacity building. Comparative Political Studies, 42(11), 1379-1402. doi: $10.1177 / 0010414009332129$

Gutiérrez, K., \& Vossoughi, S. (2010, JanuaryFebruary). Lifting off the ground to return anew: Mediated praxis, transformative learning, and social design experiments. Journal of Teacher Education, 61(1-2), 100117. doi: $10.1177 / 0022487109347877$

Harreveld, R. E. (2010). A capability approach to open and distance learning for in-service teacher education. In P. A. Danaher \& A. Umar (Eds.), Teacher education through open and distance learning (Perspectives on distance education) (pp. 47-60). Vancouver, BC: Commonwealth of Learning.

Harreveld, R. E., \& Singh, M. (2008). Amartya Sen's capability approach and the brokering of learning provision for young adults. Vocations and Learning, 1, 211-226. doi: 10.1007/s12186-008-9012-3

Janks, H. (2012). The discipline and craft of academic writing: Building and writing capacity in institutions of higher education. Reading \& Writing: Journal of the Reading Association of South Africa, 3(1), article 25. doi: 10.4102/rw.v3i1.25

Komarraju, M., Karau, S. J., Schmeck, R. R., \& Avdic, A. (2011, September). The Big Five personality traits, learning styles, and academic achievement. Personality and Individual Differences, 51(4), 472-477. Retrieved from http://www.sciencedirect.com/science/art icle/pii/S0191886911002194

Krippendorff, K. (2012). Content analysis: An introduction to its methodology ( $3^{\text {rd }}$ ed.). Thousand Oaks, CA: Sage Publications.

Kucukaydin, I., \& Cranton, P. (2012a). Critically questioning the discourse of transformative learning theory. Adult Education Quarterly, 63(1), 43-56. doi: $10.1177 / 0741713612439090$

Kucukaydin, I., \& Cranton, P. (2012b). Participatory learning in formal adult education contexts. International Journal of Adult Vocational Education and Technology, 3(1), 1-12. doi: 10.4018/javet.2012010101
Lee, S. J., Srinivasan, S., Trail, T., Lewis, D., \& Lopez, S. (2011, July). Examining the relationship among student perception of support, course satisfaction, and learning outcomes in online learning. The Internet and Higher Education, 14(3), 158-163. Retrieved from http://www.sciencedirect.com/science/art icle/pii/S1096751611000236

Mackinlay, E., \& Barney, K. (2010). Transformative learning in first year Indigenous Australian studies: Posing problems, asking questions and achieving change. A practice report. The International Journal of the First Year in Higher Education, 1(1), 91-99. Retrieved from https://fyhejournal.com/article/view/27

McConachie, J., \& Simpson, J. (2003). Social entrepreneurship: An Australian university transforms a regional community through diversity and innovation. Queensland Journal of Educational Research, 19(2), 100118. Retrieved from http://www.iier.org.au/qjer/qjer19/mcco nachie.html

Mezirow, J. (2012). Learning to think like an adult: Core concepts of transformation theory. In E. Taylor, P. Cranton, \& Associates (Eds.), The handbook of transformative learning: Theory, research, and practice (pp. 73-96). San Francisco, CA: Jossey-Bass.

Newman, M. (2012). Calling transformative learning into question: Some mutinous thoughts. Adult Education Quarterly: A Journal of Research and Theory, 62(1), 36-55. doi: $10.1177 / 0741713610392768$

Patrick, J., \& Ijah, C. (2012). Adult and non-formal education programmes of nongovernmental organizations for poverty alleviation in Nigeria: What can be learnt from the practice? Journal of Education and Practice, 3(11), 1-6. Retrieved from http://www.iiste.org/Journals/index.php/I $\mathrm{EP} /$ article/view/2536

Sen, A. (1999). Development as freedom: Human capability and global need. New York, NY: Knopf.

Silverman, D. (2011). Interpreting qualitative data (4th ed.). London, UK: Sage Publications. 
Simpson, J., McConachie J., Coombes, P., Danaher, G., Harreveld, R., \& Danaher, P. (2003). Contesting 'transitions' and (re-)engaging with 'subjectivities': Locating and celebrating the habitus in three versions of 'the first year experience' at Central Queensland University. In D. Nulty \& N. Meyers (Eds.), $7^{\text {th }}$ Pacific Rim first year in higher education conference proceedings (11 pp.). Brisbane, Australia: Queensland University of Technology.

Sugrue, C. (2011, November). Irish teachers' experience of professional development: Performative or transformative learning? Professional Development in Education, 37(5), 793-815. doi: $10.1080 / 19415257.2011 .614821$

Swanborn, P. (2010). Case study research: What, why and how? London, UK: Sage Publications.

Taylor, E., Cranton, P., \& Associates (Eds.) (2012). The handbook of transformative learning: Theory, research, and practice. San Francisco, CA: Jossey-Bass.

Van Dijk, T. (Ed.) (2011). Discourse studies: A multidisciplinary introduction $\left(2^{\text {nd }}\right.$ ed.). London, UK: Sage Publications.

Willans, J. (2010). Navigating personal change: Transforming perceptions of self as learner. Unpublished Doctor of Education dissertation, Faculty of Arts, Business, Informatics and Education, Central Queensland University, Rockhampton, Australia.

Willans, J., Harreveld, R., \& Danaher, P. (2003). Enhancing higher education transitions through negotiated engagement of learning experiences: Lessons from a preundergraduate preparatory program language education course. Queensland Journal of Educational Research, 19(1), 4250. Retrieved from http://www.iier.org.au/qjer/qjer19/willan s.html 